\title{
Socio-economics: a propensity of self-medication among OPD patients of a teaching hospital
}

\author{
Subha Sankar Chattopadhyay, Angana Datta*, Aritra Ghosh, Suvadip Biswas, \\ Krishnendu Mandal, Supreeti Biswas
}

Department of Pharmacology, Burdwan Medical College and Hospital, Burdwan 713104, West Bengal, India

Received: 16 October 2016 Accepted: 17 November 2016

*Correspondence to:

Dr. Angana Datta,

Email:

dr.anganadatta26@gmail.com

Copyright: (C) the author(s), publisher and licensee Medip Academy. This is an openaccess article distributed under the terms of the Creative Commons Attribution NonCommercial License, which permits unrestricted noncommercial use, distribution, and reproduction in any medium, provided the original work is properly cited.

\begin{abstract}
Background: Use of over the counter (OTC) drug is very much common in India. Not only medical professionals or educated urban population but also it is common in rural area and low educated person. This study was done to assess the extent of knowledge and practices of OTC drugs among OPD patients of a tertiary care hospital.

Methods: A questionnaire based study was conducted among 1680 Medicine OPD (outpatient department) patients.

Results: Among the participants, 62\% patients taking OTC drugs at least once in their life. Most common symptoms for self-medication were fever (89\%), cough and cold $(78 \%)$, headache $(67 \%)$, pain $(53 \%)$, diarrhea $(10 \%)$, vomiting $(10 \%)$, indigestion (20\%). Antipyretics $(65 \%)$, analgesics $(35 \%)$ among NSAIDs which were common used as OTC drugs. Others drugs were antacids (50\%), cough and cold preparations (50\%), Vitamins (30\%), antiemetics (5\%). Conclusions: Awareness is necessary to use drugs rationally with proper prescription and know about harmful effects of OTC drugs.
\end{abstract}

Keywords: Awareness, NSAIDs, Over the counter drug, Proper prescription, Questionnaire

\section{INTRODUCTION}

'Over the counter' (OTC) drugs mean drugs legally allowed to be sold over the counters without prescription of a Registered Medical Practitioner. ${ }^{1}$ In India CDSCO regulates import, manufacture, distribution and sale of drug and cosmetics by drugs and cosmetics act (DCA) and its subordinate legislation, drugs and cosmetic rules (DCR), 1940. All the non - prescription drugs which are sold over the counter to the general population also fall under these act and legislation. Prescription drugs fall under two schedules of the drug and cosmetics rule, 1945 schedule $\mathrm{H}$ and Schedule X. The Ministry of Health and Family Welfare in India published a notification in 2012 to incorporate a separate schedule $\mathrm{H}_{1}$ under the drugs and cosmetics rule, 1945 for regulating sale of antibiotics, certain anti-TB drugs and habit forming drugs; to decrease uncontrollable use of OTC drugs. Trend of using OTC drugs is high in India. Self medication increases the chances of illicit use of drugs and drug dependency. ${ }^{2}$ Due to uncontrolled use of OTC drugs, signs and symptoms of underlying diseases are suppressed, hence incidence of delayed diagnosis, complications, treatment failure and drug resistance are increasing. ${ }^{3-6}$ In several studies it has been shown that resistance of pathogen, ADR and drug dependence increase due to inappropriate use of drugs without expert opinion. ${ }^{7-9}$

In our society it is a common practice to treat most illness by self medication. Due to lack of doctors in rural settings, low socio economic status and illiteracy many of our rural people buy OTC drugs from nearby medicine shops. ${ }^{10}$ Very commonly they use non-steroidal anti- 
inflammatory drugs (NSAIDs) as OTC drugs for several ailments. Besides this, they also use other drugs (other than NSAIDS) as OTC drugs.

In this scenario we planned a study to assess the level of knowledge and practice of OTC drugs, principally NSAIDs and others among the patients in Medicine Outpatient Department (MOPD) of a tertiary care Government Medical College and Hospital.

\section{Objectives}

1. To assess knowledge, practices of self medication by OTC drug use among MOPD patients.

2. To assess the reasons of using OTC drugs most.

3. To know which groups of drugs mainly used by them.

\section{METHODS}

A cross-sectional questionnaire based descriptive study was conducted for a period of 4 months in the MOPD in Burdwan Medical College and Hospital from October 2015 to January 2016. Patients attending MOPD of Burdwan Medical College and Hospital were selected for this study. With prior consent, patients were administered open questions regarding use, reason of use, indications of use and type of OTC drugs used. Responses of the questions were noted in the questionnaire sheets. Data were entered in excel sheet and analysed with SPSS method.

\section{RESULTS}

Total 1680 patients in the MOPD during 3 months period were examined. Among them, $62 \%$ of patients $(n=1042)$ taking OTC drugs.

Table 1: Demographic profile of the encountered in the MOPD regarding OTC drug use ( $\mathrm{N}=1680)$.

\begin{tabular}{|c|c|c|c|}
\hline Parameters & $\begin{array}{l}\text { Encountered } \\
\text { patients } \\
(\mathrm{N}=1680) \\
\text { No }(\%)\end{array}$ & $\begin{array}{l}\text { Users } \\
(n=1042) \\
\text { No }(\%)\end{array}$ & $\begin{array}{l}\text { Non users } \\
{[(\mathbf{N}-\mathbf{n})} \\
=638] \\
\text { No }(\%)\end{array}$ \\
\hline $\begin{array}{l}\text { Residence } \\
\text { Rural } \\
\text { Urban }\end{array}$ & $\begin{array}{l}1075(64) \\
605(36)\end{array}$ & $\begin{array}{l}729(69 \%) \\
313(31 \%)\end{array}$ & $\begin{array}{l}128(21 \%) \\
510(79 \%)\end{array}$ \\
\hline $\begin{array}{l}\text { Sex } \\
\text { Male } \\
\text { Female }\end{array}$ & $\begin{array}{l}806(48) \\
874(52)\end{array}$ & $\begin{array}{l}468(45 \%) \\
574(55 \%)\end{array}$ & $\begin{array}{l}351(55 \%) \\
287(45 \%)\end{array}$ \\
\hline $\begin{array}{l}\text { Educational stat } \\
\text { Illiterate } \\
\text { Primary } \\
\text { Secondary< }\end{array}$ & $\begin{array}{l}538(32) \\
588(35) \\
554(33)\end{array}$ & $\begin{array}{l}417(40 \%) \\
365(35 \%) \\
260(25 \%)\end{array}$ & $\begin{array}{l}128(20 \%) \\
191(30 \%) \\
319(50 \%)\end{array}$ \\
\hline $\begin{array}{l}\text { Employment sta } \\
\text { Day laborers } \\
\text { Service holders } \\
\text { Businessman }\end{array}$ & $\begin{array}{l}\text { Is } \\
806(48) \\
269(16) \\
605(36)\end{array}$ & $\begin{array}{l}625(60 \%) \\
104(10 \%) \\
313(30 \%)\end{array}$ & $\begin{array}{l}128(20 \%) \\
319(50 \%) \\
191(30 \%)\end{array}$ \\
\hline
\end{tabular}

On the contrary $38 \%(n=638)$ not taking any OTC drugs (Table 1).

Reasons of using OTC drugs are various. $64 \%$ of patients used OTC drugs due to lack of physicians in rural, $60 \%$ due to dependence of quack, $64 \%$ due to less time waste, $50 \%$ due to low socio economic condition, $40 \%$ due to loss of earning, only $16 \%$ due to ignorance (Table 2 ).

Table 2: Reasons for taking NSAIDs and others as OTC drugs $(n=1042)$.

\begin{tabular}{|ll|}
\hline Reasons for using OTC drugs & Response no $(\%)$ \\
\hline $\begin{array}{l}\text { Lack of recognized physician in } \\
\text { rural }\end{array}$ & $667(64)$ \\
\hline Dependence on quack & $625(60)$ \\
\hline Less time waste & $667(64)$ \\
\hline Low socio economic condition & $521(50)$ \\
\hline Loss of earning & $417(40)$ \\
\hline Ignorance & $167(16)$ \\
\hline
\end{tabular}

So there are overlapping reasons for using OTC drugs.

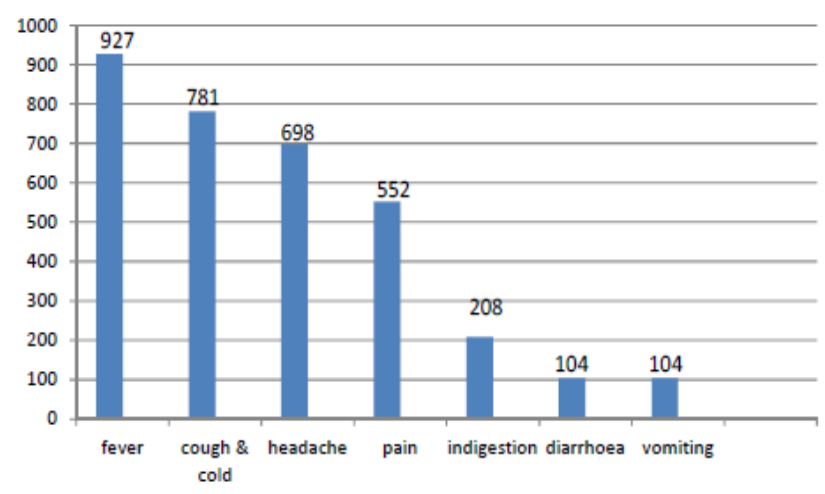

Figure 1: General Indications of OTC drugs $(n=1042)$.

From Figure 1 it is seen that $89 \%$ (927) of them used OTC drugs due to fever, $75 \%$ (781) due to cough and cold, $67 \%$ (698) due to headache,53\% (552) due to pain, $20 \%$ (208) due to indigestion, $10 \%$ (104) due to diarrhea, $10 \%$ (104) due to vomiting.

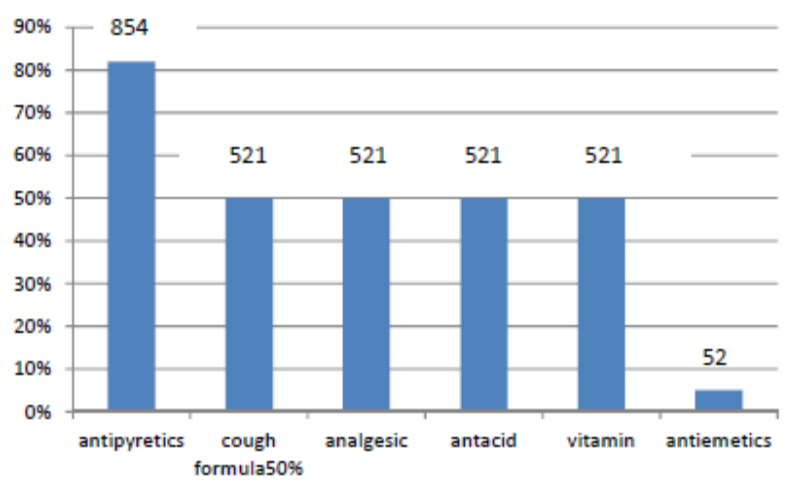

Figure 2: Class of commonly used OTC drugs $(n=10420)$. 
Figure 2 shows the class of commonly used drugs which were antipyretics (82\%), drugs for common cold $(50 \%)$, analgesics $(50 \%)$, antacids $(50 \%)$, vitamins $(50 \%)$, antiemetics (5\%) among OTC drugs.

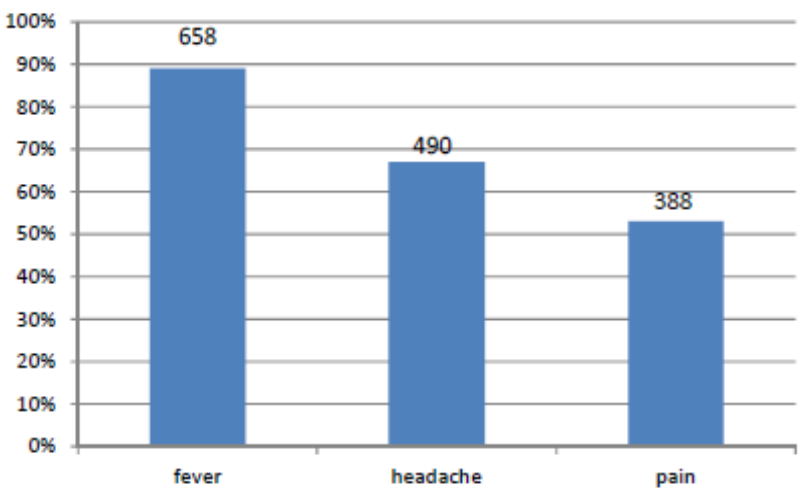

Figure 3: Indications for NSAIDs as OTC drugs (n1=732).

From Figure 3 indications of NSAIDs use are fever $(89 \%)$, headache $(67 \%)$, pain $(53 \%)$. So it is seen there are considerable overlapping in indications of NSAIDs use.

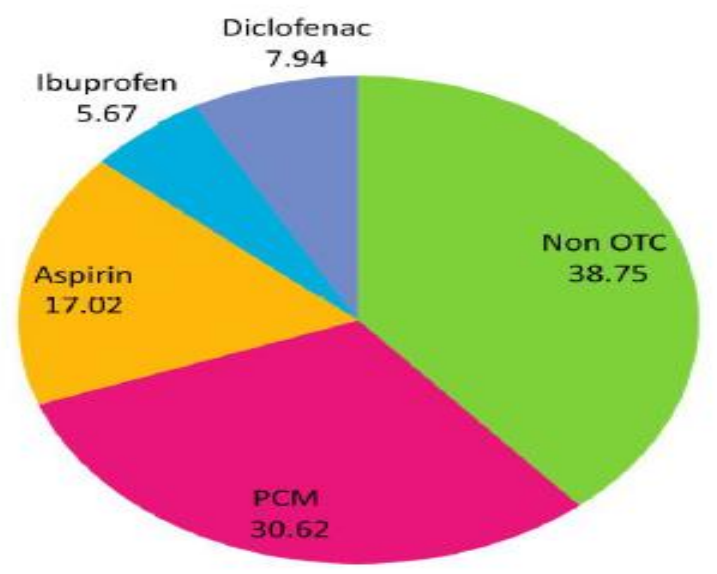

Figure 4: Specific OTC drugs used by the patients according to their generic name $(\mathrm{N}=1680)$.

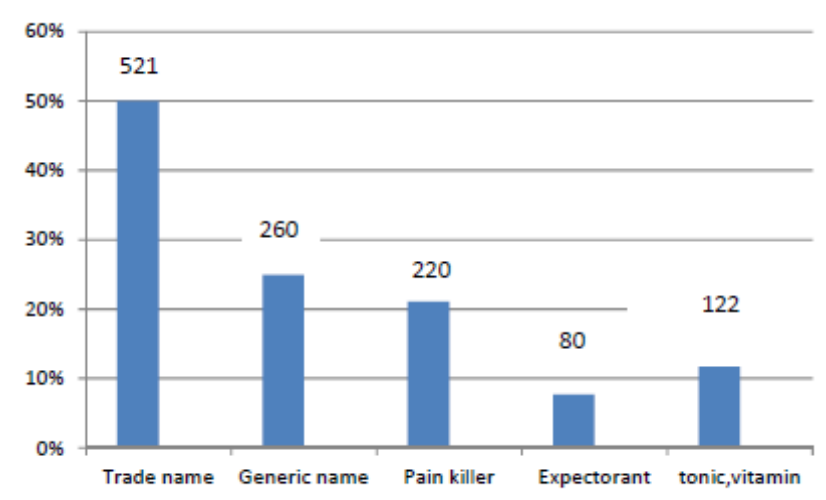

Figure 5: Nomenclature of drugs uttered by the patients $(n=1042)$.
According to Figure 4 almost $7.94 \%$ use diclofenac, $5.67 \%$ use ibuprofen, $17.02 \%$ use aspirin, $30.62 \%$ use paracetamol.

According to Figure 5 almost $50 \%$ of patients (521) utter the trade name of OTC drugs,24.9\% (260) of patients utter even generic name, $21.1 \%$ (220) described as 'pain killer', $7 \%$ (80) described as expectorant. $11.7 \%$ describe OTC drug as 'tonic'.

\section{DISCUSSION}

Use of OTC drug and self- medication is becoming an increasingly important area within healthcare. WHO considers self- medication as part of self- care that helps efficient use of health care system. ${ }^{14}$ The recent trend is to expand the list of OTC medicines and to increase availability of controlled drug, this will give more liberty and choice to the people to take informed treatment decisions. ${ }^{12}$ In this context the study was shown that it is prevalent in common people in rural settings. In our study it was found that more than half $(62 \%)$ patients taking OTC drug. Impact of demographic profile on OTC drugs use is also done in our study. Along with $64 \%$ of rural and $36 \%$ of urban populations also use OTC drugs . The study showed female (52\%) dominancy in using OTC drugs. Educational status also affects OTC users. Lower educational status appear more incumbency in using OTC drugs $32 \%$ illiterate, $36 \%$ primary educated and $32 \%$ secondary educated patients use OTC drugs. Day labourer has highest propensity of using OTC drugs $48 \%$. Whereas businessman $35 \%$ and service sector $16.2 \%$ use OTC drugs in their life. Reasons for using OTC drugs are lack of recognized physician (64\%), dependence on quack $(60 \%)$, less time waste $(64 \%)$, only $(16 \%)$ said they used due to ignorance. Low earning, lack of jobs and other socioeconomic factors play important role in using OTC drugs.

Results are more or less similar to those reported in other studies. ${ }^{11,13}$ In the study it was noticed that the classes of drugs that were commonly used were antipyretics $(82 \%)$, cough and cold formula (50\%), analgesics (50\%), antacids (50\%), vitamins (50\%), antiemetics (5\%). Among NSAIDs antipyretics $65 \%$ analgesics $35 \%$ were used. In more than $30 \%$ of cases patient utter the trade name of the drug. Almost $50 \%$ of patients taking OTC drugs under trade names.

\section{Limitation}

The limitations of this study include absence of a comparative group, such as subjects from another field, small sample size, not a prospective study and absence of interventions.

\section{CONCLUSION}

The cross sectional study shows that the use of OTC drugs is common among MOPD patients. More than half 
of the patients use NSAIDS as OTC drugs. Though it was non comparative study, comparison between OTC drug users and non users could be possible. Restriction of sale of drugs with potentially harmful effects should be implemented efficiently with monitoring systems between physicians and pharmacists. Steps can also be taken to educate pharmacists on the need to cross check with the prescribing physician while dispensing such drugs. Awareness is necessary to use drugs rationally with prior prescription and not to take OTC drugs. Mass education and awareness to general people is required for rational drug use.

Funding: No funding sources

Conflict of interest: None declared

Ethical approval: The study was approved by the Institutional Ethics Committee

\section{REFERENCES}

1. Food and Drug Administration (FDA). FDA glossary of Terms; 2010 [cited 2011 July 15]. Available from http:// www.fda.gov/ Drugs/information drugs/ucm079436: htm.

2. Mccabe SE, Teter CJ, Boyde CJ. Illicit use of prescription pain medication among college students. Drug and Alcohol Dependence. 2005 Jan 7;77(1):3747.

3. Ferris DG, Nyirjesy P, Sobel JD, Pavletic A, Litaker MS. Over-the-counter antifungal drug misuse associated with patient-diagnosed vulvovaginal candidiasis. Obstet Gynecol. 2002 Mar;99(3):419-25.

4. Calabresi P, Cupini LM. Medication-overuse headache: similarities with drug addiction. Trends Pharmacol Sci. 2005 Feb;26(2):62-8.

5. French L, Horton J, Matousek M. Abnormal vaginal discharge: What does and does not work in treating underlying causes. J Fam Pract. 2004 Nov;53(11):890-4.

6. Ashina $\mathrm{S}$, Zeeberg $\mathrm{P}$, Jensen $\mathrm{RH}$, Ashina $\mathrm{M}$. [Medication overuse headache]. Ugeskr Laeger. 2006 Mar 6;168(10):1015-9.
7. Badiger S, Kundapur R, Jain A, Kumar A, Pattanshetty S, Thakolkaran N et al. Self-medication pattern among medical students in South India. Australas Med J. 2012;5(4):217-20.

8. James H, Handu SS, Al Khaja KA, Otoom S, Sequeira RP. Evaluation of the Knowledge, Attitude and Practice of Self-Medication among First-Year Medical Students. Med Princ Pract. 2006;15(4):270-5.

9. Hem E, Stokke G, Tyssen R, Grønvold NT, Vaglum $\mathrm{P}$, Ekeberg O. Self-prescribing among young Norwegian doctors: a nine-year follow-up study of a nationwide sample. BMC Medicine. 2005;3:16.

10. Pagane JA, Ross S, Yaw J, Polsky D. Self medication and health insurance coverage in Mexico. Health policy. 2007;75:170-7.

11. Martins AP, Miranda AC, Mendes Z, Soares MA, Ferreira P, Nogueira A. Self-medication in a Portuguese urban population: a prevalence study. Pharmacoepidemiol Drug Saf. 2002 JulAug;11(5):409-14.

12. Shankar PR, Partha P, Shenoy N. Self-medication and non- doctor prescription practices in Pokhara Valley, Western Nepal: A questionnaire based study. BMC Family Practice. 2002 Oct;3(1):17.

13. Bretagne JF, Richard-Molard B, Honnorat C, Caekaert A, Barthelemy P. [Gastroesophageal reflux in the French general population: national survey of 8000 adults]. Presse Med. 2006 Jan;35(1 Pt 1):23-31.

14. World Health Organization (WHO). Guidelines for the regulatory assessment of medicinal products for use in self-medication; 2000. Available from http://apps.who.int/medicinedocs/en/d/Js2218e/

Cite this article as: Chattopadhyay SS, Datta A, Ghosh A, Biswas S, Mandal K, Biswas S. Socioeconomics: a propensity of self-medication among OPD patients of a teaching hospital. Int J Basic Clin Pharmacol 2017;6:104-7. 